\title{
Effect of Hydrogeochemical Processes on the Quality of Groundwater around Coastal Shallow aquifer in Tg Labian, Lahad Datu Sabah
}

\author{
Baba Musta
}

\begin{abstract}
This paper discussed the hydrogeochemical properties of groundwater collected around coastal shallow aquifer in Kg Tanjung Labian FELDA Sahabat Lahad Datu, Sabah, Malaysia. In this study three boreholes were constructed namely $\mathrm{BH}-1, \mathrm{BH} 2$ and $\mathrm{BH} 3$. The main objective of this study is to measure the concentration of major elements and selected trace elements in the groundwater samples; and to identify the minerals in soil samples. The groundwater samples were collected at the depth of 3 meter, 5 meter and 7 meter. Soil sample were collected for mineralogical identification using XRD method and indicates the appearance of quartz and calcite. The analysis of major elements and trace metals in water were carried out using ICP-OES instrument. The result of in-situ parameters analysis indicates that all groundwater samples collected from the Boreholes shows the very weak acidic to neutral $\mathrm{pH}$ values that ranged from 6.8 to 7.6. Dissolved oxygen (DO) concentrations were found to be relatively high at $\mathrm{BH}-3$, whereas $\mathrm{BH}-1$ had a low dissolved oxygen level in the groundwater. Highly mineralised samples were measured at all three Boreholes. Groundwater samples with Total Dissolved Solid (TDS) were mainly due to dissolution of carbonate rock from the Togopi Formation into the water. Thus, all samples were found to have exceeded the WHO (World Health Organisation) limits for TDS. Groundwater samples collected from all boreholes also reported higher EC value due to the high dissolved materials released from the rock in the boreholes. Overall, Fe was found to be high $(0.38-1.89 \mathrm{mg} / \mathrm{L})$ in all of the groundwater samples collected at the three Boreholes whereas, other trace elements such as $\mathrm{Ag}, \mathrm{As}, \mathrm{Ba}, \mathrm{Cu}, \mathrm{Ni}, \mathrm{Pb}$ and $\mathrm{Zn}$ were found to be acceptable with the WHO limits. Borehole-2 was found to exceed the WHO limits for Manganese $(0.31-0.36 \mathrm{mg} / \mathrm{L})$ whereas other sampling stations remained low. Most samples measured for $\mathrm{Pb}$ and Se had exceeded the WHO limits of 0.1 $\mathrm{mg} / \mathrm{L}$, suggesting that currently the groundwater was not suitable for consumption and further detail observation should be carry on.
\end{abstract}

Keywords-hydrogeochemistry, groundwater, water quality , mineralogy, carbonate rock

Baba Musta, Mohamed Ali Mohd Yusuf,

Hardianshah Saleh \& Nur Fahdleena Ali Ngasio

Programme of Geology

Science and Technology Complex

Faculty of Science and Natural Resources

Universiti Malaysia Sabah

88400, Kota Kinabalu, Sabah, Malaysia 